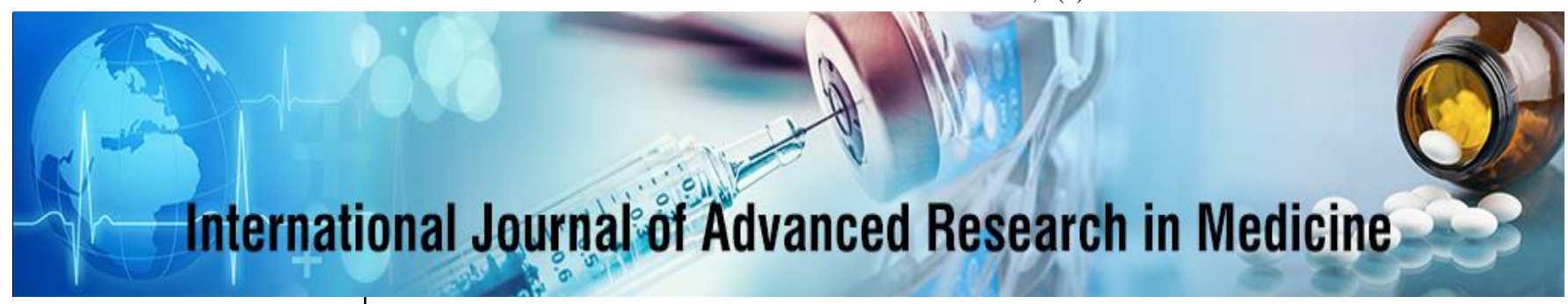

E-ISSN: 2706-9575

P-ISSN: 2706-9567

IJARM 2021; 3(1): 72-74

Received: 08-11-2020

Accepted: 12-12-2020

Shirish D Chavan

Associate Professor,

Department of Tuberculosis

and Chest Diseases, PIMS\&R,

Islampur, Maharashtra, India

Vijay S Patil

Professor, Department of

Community Medicine,

PIMS\&R, Islampur,

Maharashtra, India
Corresponding Author: Vijay S Patil

Professor, Department of

Community Medicine,

PIMS\&R, Islampur,

Maharashtra, India

\section{Assessment of serum levels of C-reactive proteins as an indicator of disease activity in pulmonary tuberculosis}

\author{
Shirish D Chavan and Vijay S Patil
}

DOI: https://doi.org/10.22271/27069567.2021.v3.i1b.104

\begin{abstract}
Background: Tuberculosis (TB) is an infectious disease caused by Mycobacterium tuberculosis. The present study was conducted to assess serum levels of C-reactive proteins as an indicator of disease activity in pulmonary tuberculosis.

Materials and Methods: This cross-sectional study was conducted with 60 new sputum-positive pulmonary tuberculosis cases and 60 healthy subjects in 2020. Baseline serum C-reactive proteins (CRP) levels were measured and the values were correlated to clinical and radiological findings. Results: The mean CRP level (mg/dl) in patients with fever was $66.5 \mathrm{mg} / \mathrm{dl}$ and it was $28.2 \mathrm{mg} / \mathrm{dl}$ among those without fever. Mean level off CRP in haemoptysis was $50.3 \mathrm{mg} / \mathrm{dl}$ and $54.2 \mathrm{mg} / \mathrm{dl}$ in those without haemoptysis. Mean levels of CRP were $76.2 \mathrm{mg} / \mathrm{dl}$ and $26.5 \mathrm{mg} / \mathrm{dl}$ among those with and without tachycardia respectively. Mean level was $78.4 \mathrm{mg} / \mathrm{dl}$ with tachypnoea and $27.1 \mathrm{mg} / \mathrm{dl}$ among those with no tachypnoea. The mean CRP level in patients with minimal disease was $24.2 \mathrm{mg} / \mathrm{dl}$, and with moderate disease it was $41.8 \mathrm{mg} / \mathrm{dl}$ and with advanced disease it was $90.5 \mathrm{mg} / \mathrm{dl}(P<0.05)$. Conclusion: CRP levels in Pulmonary tuberculosis patients before initiating anti-tubercular therapy showed a positive correlation with clinical features and radiological severity.
\end{abstract}

Keywords: CRP, pulmonary tuberculosis, radiological severity

\section{Introduction}

Tuberculosis (TB) is an infectious disease caused by Mycobacterium tuberculosis and mainly affects lungs. It is estimated that between $19 \%$ and $43 \%$ of the world's population is infected with Mycobacterium tuberculosis. ${ }^{1}$ In spite of substantial investments in global tuberculosis (TB) control, TB incidence remains high, with over 9 million TB cases in 2013 alone. High-risk groups such as HIV positive persons contribute significantly to the caseload of pulmonary TB. The World Health Organization (WHO) now recommends systematic screening of high-risk groups, but the lack of an accurate yet simple screening tool is a key barrier ${ }^{[2]}$. A good screening test would rule-out TB in the majority of patients without disease and limit referrals for more costly positive testing to patients with a high likelihood of having TB. A test with these characteristics that is also low-cost and can be performed by front-line health workers has been ranked among the highest priority needs for TB diagnostics ${ }^{[3]}$.

C-reactive protein (CRP) is produced by the liver in response to inflammation and its levels are also elevated in patients with pulmonary tuberculosis ${ }^{[4]}$. At present, there is insufficient information correlating CRP levels to clinical findings, radiological severity and response to anti-tubercular treatment ${ }^{[5]}$. The identification of biomarkers that are predictive of adverse outcomes can help in risk stratification of patients for early intervention and better patient management. Biomarkers for early detection of treatment failure measurable during early treatment of TB may help in identification and shifting of these patients to newer drugs ${ }^{[6]}$. The present study was conducted to assess serum levels of CRP as an indicator of disease activity in pulmonary tuberculosis.

\section{Materials and Methods}

This cross-sectional study comprised of 60 patients with new sputum positive pulmonary tuberculosis and 60 healthy subjects in Prakash institute off medical sciences and research, Islampur in 2020. Diagnosis of pulmonary TB was based on symptoms, $\mathrm{x}$-ray findings and 
positive sputum smear microscopy for M tuberculosis. Acter obtaining ethical clearance and obtaining consent, besides name socio-demographic data such as age, gender, region was collected. Before initiating treatment, baseline serum CRP levels were measured and the values were correlated to clinical and radiological findings. Serum CRP levels were correlated with age, BMI, presence or absence of fever, dyspnoea, haemoptysis, tachycardia, tachypnoea, hypotension, respiratory distress and mortality. Statistical significance was tested using t-test. A P-value of less than 0.05 was considered statistically significant.

\section{Results}

The study comprised 120 subjects and $66.6 \%$ were males (80) and $33.4 \%$ were females (40). Table 1 shows the mean serum CRP levels in those with clinical finding and those without. The mean CRP level $(\mathrm{mg} / \mathrm{dl})$ in patients with fever was $66.5 \mathrm{mg} / \mathrm{dl}$ and it was $28.2 \mathrm{mg} / \mathrm{dl}$ among those without fever. Mean level off CRP in haemoptysis was $50.3 \mathrm{mg} / \mathrm{dl}$ and $54.2 \mathrm{mg} / \mathrm{dl}$ in those without haemoptysis. Mean levels of CRP were $76.2 \mathrm{mg} / \mathrm{dl}$ and $26.5 \mathrm{mg} / \mathrm{dl}$ among those with and without tachycardia respectively $(P<0.02)$. Mean level was $78.4 \mathrm{mg} / \mathrm{dl}$ with tachypnoea and $27.1 \mathrm{mg} / \mathrm{dl}$ among those with no tachypnoea. The mean CRP level in patients with minimal disease was $24.2 \mathrm{mg} / \mathrm{dl}$, and with moderate disease it was $41.8 \mathrm{mg} / \mathrm{dl}$ and with advanced disease it was $90.5 \mathrm{mg} / \mathrm{dl}(P<0.05)$. Mean CRP level was $104.2 \mathrm{mg} / \mathrm{dl}$ in those with hypotension and $43.7 \mathrm{mg} / \mathrm{dl}$ in those without hypotension $(P<0.01)$. Mean CRP level were $94.5 \mathrm{mg} / \mathrm{dl}$ and $35.5 \mathrm{mg} / \mathrm{dl}$ in subjects with and without respiratory distress $(P<0.05)$. Table 2 shows that mean CRP level $(\mathrm{mg} / \mathrm{dl})$ in patients with minimal disease was $24.2 \mathrm{mg} / \mathrm{dl}$, with moderate disease was $41.8 \mathrm{mg} / \mathrm{dl}$, and with advanced disease was $90.5 \mathrm{mg} / \mathrm{dl}$. The difference was statistically significant $(P<0.05)$.

Table 1: Mean CRP levels (mg/dl) in patients with and without clinical findings $(\mathrm{N}=120)$

\begin{tabular}{|c|c|c|c|}
\hline Clinical finding & $\begin{array}{c}\text { Clinical finding } \\
\text { present }\end{array}$ & $\begin{array}{c}\text { Clinical finding } \\
\text { absent }\end{array}$ & $\boldsymbol{P}$ value \\
\hline Fever & 66.5 & 28.2 & 0.05 \\
\hline Haemoptysis & 50.3 & 54.2 & 0.19 \\
\hline Tachycardia & 76.2 & 26.5 & 0.02 \\
\hline Tachypnoea & 78.4 & 27.1 & 0.04 \\
\hline Hypotension & 104.2 & 43.7 & 0.01 \\
\hline Respiratory distress & 94.5 & 35.5 & 0.05 \\
\hline
\end{tabular}

Table 2: CRP levels and radiological severity of disease $(\mathrm{N}=120)$

\begin{tabular}{|c|c|c|}
\hline Radiological severity & Mean mg/dl & P value \\
\hline Minimal disease & 24.2 & \\
\hline Moderate disease & 41.8 & \multirow{2}{*}{0.04} \\
\hline Advanced disease & 90.5 & \\
\hline
\end{tabular}

\section{Discussion}

Current TB screening tools endorsed by the WHO are insufficient and include symptom assessment and chest radiography (CXR) ${ }^{[7]}$. A symptom-based approach to TB screening requires a priori knowledge of the patient's HIV status to be sufficiently sensitive and has poor specificity for active TB, particularly among key high-risk groups such as people living with HIV ${ }^{[8]}$. Although CXR is sufficiently sensitive and has higher specificity, it requires costly infrastructure and trained interpreters, both of which are often absent in lower-level health centres where most patients with symptoms suggestive of TB first present for care. To simplify scale-up of systematic screening of highrisk groups, there is an urgent need to recognize an accurate and practical screening tool ${ }^{[9]}$. C-reactive protein (CRP) is an acute phase reactant whose levels rise in response to IL-6 mediated pyogenic infections such as active TB. Previous studies have consistently shown CRP to have high sensitivity for TB and that TB-associated elevations in CRP levels are independent of HIV status. In addition, CRP can be measured using a low-cost, point-of-care (POC) assay [10]. The present study was conducted to assess serum levels of C-reactive proteins as an indicator of disease activity in pulmonary tuberculosis.

In present study, we observed that the mean serum CRP levels in those with clinical finding and those without. The mean CRP level $(\mathrm{mg} / \mathrm{dl})$ in patients with fever was 66.5 $\mathrm{mg} / \mathrm{dl}$ and it was $28.2 \mathrm{mg} / \mathrm{dl}$ among those without fever. Mean level off CRP in haemoptysis was $50.3 \mathrm{mg} / \mathrm{dl}$ and $54.2 \mathrm{mg} / \mathrm{dl}$ in those without haemoptysis. Mean levels of CRP were $76.2 \mathrm{mg} / \mathrm{dl}$ and $26.5 \mathrm{mg} / \mathrm{dl}$ among those with and without tachycardia respectively $(P<0.02)$. Mean level was $78.4 \mathrm{mg} / \mathrm{dl}$ with tachypnoea and $27.1 \mathrm{mg} / \mathrm{dl}$ among those with no tachypnoea. Mean CRP level were $94.5 \mathrm{mg} / \mathrm{dl}$ and $35.5 \mathrm{mg} / \mathrm{dl}$ in subjects with and without respiratory distress $(P<0.05)$. Sharma et al. ${ }^{[11]}$ conducted a study on 50 new sputum-positive pulmonary $\mathrm{TB}$ patients and 50 healthy individuals. The patients were evaluated for clinical and radiological findings, which were correlated to baseline CRP levels. CRP levels were measured at 2 months and after completion of treatment and correlated to treatment end results. Mean baseline CRP levels in pulmonary tuberculosis patients were $55.32 \mathrm{mg} / \mathrm{L}$ (range $16-144 \mathrm{mg} / \mathrm{L}$ ). CRP levels among normal healthy individuals were 4.46 $\mathrm{mg} / \mathrm{L}$ (range $2-8 \mathrm{mg} / \mathrm{L}$ ). CRP levels were significantly higher in TB patients with fever, tachycardia, tachypnoea, hypotension, respiratory distress and the need for ventilatory support when compared to patients without these features. The study showed significant correlation between CRP levels and radiological extent of disease. Baseline CRP levels were significantly higher in mortality group when compared to survivor group. CRP levels showed progressive decline in patients who were cured. We observed that mean CRP level in patients with minimal disease was $24.2 \mathrm{mg} / \mathrm{dl}$, with moderate disease was $41.8 \mathrm{mg} / \mathrm{dl}$ and with advanced disease was $90.5 \mathrm{mg} / \mathrm{dl}$. Caner SS et al., ${ }^{[12]}$ showed that CRP levels were significantly higher in patients with fever. Another study by Kaminskaia GO et al., ${ }^{[13]}$ showed similar correlation between degree of intoxication and CRP levels.

\section{Conclusion}

Authors found that CRP levels in pulmonary tuberculosis patients before initiating anti-tubercular therapy showed a positive correlation with clinical features and radiological severity.

\section{References}

1. Kim CW, Kim S, Lee SN, Lee SJ, Lee MK, Lee JH et al. Risk Factors Related with Mortality in Patient with Pulmonary Tuberculosis. Tuberc Respir Dis 2012;73:38-47.

2. Shameem M, Fatima N, Ahmad A, Malik A, Husain Q. Correlation of Serum C-Reactive Protein with Disease Severity in Tuberculosis Patients. Open Journal of Respiratory Diseases 2012;2:95-100. 
3. Lee JH, Chang JH. Changes of plasma interleukin-1 receptor antagonist, interleukin-8 and other serologic markers during chemotherapy in patients with active pulmonary tuberculosis. Korean J Intern Med 2003;18:138-45.

4. Plit ML, Theron AJ, Fickl H, Van Rensburg CE, Pendel $\mathrm{S}$, Anderson R. Influence of antimicrobial chemotherapy and smoking status on the plasma concentrations of vitamin $\mathrm{C}$, vitamin $\mathrm{E}$, beta carotene, acute phase reactants, iron and lipid peroxides in patients with pulmonary tuberculosis. Int J Tuberc Lung Dis 1998;2:590-06.

5. Pepys MB, Hirschfield GM. C-reactive protein: a critical update. J Clin Invest. June 2003;111(12):180512.

6. Kim CW, Kim S, Lee SN, Lee SJ, Lee MK, Lee JH et al. Risk Factors Related with Mortality in Patient with Pulmonary Tuberculosis. Tuberc Respir Dis 2012;73:38-47.

7. Huang CT, Lee LN, Ho CC, Shu CC, Ruan SY, Tsai YJ et al. High serum levels of procalcitonin and soluble TREM-1 correlated with poor prognosis in pulmonary tuberculosis. J Infect 2014;68(5):440-7.

8. Falk A, O'Connor JB, Pratt PC. Classification of pulmonary tuberculosis. In Falk A, O'Connor JB, Pratt PC, Webb J, Wier J, and Wolinsky E, editors. Diagnosis standards and classification of tuberculosis. New York. National Tuberculosis and Respiratory Disease Association, New York 1969;12:68-76.

9. Peresi E, Silva SM, Calvi SA, Marcondes-Machado Cytokines J. Acute phase serum proteins as markers of inflammatory regression during the treatment of pulmonary tuberculosis. J Bras Pneumol 2008;34(11):942-9.

10. Abakay O, Abakay A, Sen HS, Tanrikulu AC. The Relationship Between Inflammatory Marker Levels and Pulmonary Tuberculosis Severity. Inflammation 2015;38(2):691-6.

11. Sharma RK, Sharma R, Sharma N, Sandhu R, Sharma A, Mahajan C, Neki NS. Study of the Serum Levels of C-Reactive Proteins as an Indicator of Disease Activity in Pulmonary Tuberculosis and Monitoring Response to Treatment. Ann. Int. Med. Den. Res 2016;2(6):ME23ME27.

12. Caner SS. The relation of serum interleukin-2 and Creactive protein levels with clinical and radiological findings in patients with pulmonary tuberculosis. Tuberk Toraks 2007;55(3):238-45.

13. Kaminskaia GO, Abdullaev RI, Komissarova OG. Estimation of serum C-reactive protein values in patients with pulmonary tuberculosis. Probl Tuberk Bolezn Legk 2008;10:50-54. 